\title{
A systematic review and meta-analysis
}

9 Yu Liu ${ }^{1}$, Hua-ying Fan ${ }^{1}$, Jin-qun Hu${ }^{1}$, Ming Chen ${ }^{1}$, Jiao Chen ${ }^{*}$ 
medRxiv preprint doi: https://doi.org/10.1101/2022.01.31.22270217; this version posted February $2,2022$. The copyright holder for this preprint (which was not certified by peer review) is the author/funder, who has granted medRxiv a license to display the preprint in

It is made available under a CC-BY 4.0 International license.

\section{Abstract}

24 Objective. To perform a systematic review and meta-analysis of randomized controlled trials (RCTs) to evaluate acupuncture's clinical effect of on insulin resistance (IR) in women with polycystic ovary syndrome (PCOS).

Methods. PubMed, Cochrane Library, Embase databases, and Chinese databases, including China National Knowledge Infrastructure (CNKI), Technology Journal Database (VIP), and Wanfang Database, were searched without language restrictions

31 from inception to 20 December 2021. Only RCTs in which acupuncture had been examined as the sole or adjunctive PCOS-IR treatment were included. Additionally, only studies in Chinese databases that had been published in core journals of Peking University were included. Our primary endpoint was homeostasis model assessment of insulin resistance (HOMA-IR). The secondary outcomes were fasting blood glucose (FBG), 2-h postprandial blood glucose (2h-PBG), fasting insulin (FINS), body mass index (BMI), and adverse events. A random-effects model enabled reporting of differences between groups as mean differences, thus minimizing the effects of uncertainty associated with inter-study variability on the effects of different interventions.

Results. Our analysis included seven eligible RCTs ( $\mathrm{N}=728$ participants). Compared with other treatments, acupuncture therapy yielded a greater mean reduction in BMI

$44(-1.21 ; 95 \% \mathrm{CI},-2.41$ to $-0.02 ; \mathrm{P}=0.05)$. No significant differences existed between 
medRxiv preprint doi: https://doi.org/10.1101/2022.01.31.22270217; this version posted February $2,2022$. The copyright holder for this preprint (which was not certified by peer review) is the author/funder, who has granted medRxiv a license to display the preprint in It is made available under a CC-BY 4.0 International license.

acupuncture and other studied treatments for changes in HOMA-IR $(-0.33 ; 95 \% \mathrm{CI}$, -0.87 to $0.22 ; \mathrm{P}>0.05), \mathrm{FBG}(-0.43 ; 95 \% \mathrm{CI},-0.88$ to $0.03 ; \mathrm{P}=0.07), 2 \mathrm{~h}-\mathrm{PBG}(-0.40$; 95\% CI, -0.90 to $0.10 ; \mathrm{P}>0.05)$, and FINS $(-0.65 ; 95 \% \mathrm{CI},-2.18$ to $0.89 ; \mathrm{P}>0.05)$. Furthermore, compared with medication alone, a combination of acupuncture and medication yielded a mean reduction in HOMA-IR of -0.63 (95\% CI, -1.12 to -0.14 ; $\mathrm{P}=0.01)$ and $\mathrm{BMI}$ of $-1.36(95 \% \mathrm{CI},-2.07$ to $-0.66 ; \mathrm{P}<0.01)$.

Conclusion. Although acupuncture is not more effective than metformin, the former could be an adjuvant strategy for improving PCOS-IR. Further large-scale, longterm RCTs with strict methodological standards are justified.

Polycystic ovary syndrome (PCOS), a complex endocrine and metabolic disorder, is characterized by androgen excess (hirsutism and/or hyperandrogenemia) and ovarian dysfunction (oligo-ovulation and/or polycystic ovarian morphology). To date, its pathogenesis remains unclear. However, insulin resistance (IR) is considered the primary pathological basis for the associated reproductive dysfunction. The prevalence of IR in clamp studies in women with PCOS diagnosed on the basis of the Rotterdam criteria and using age-appropriate lean healthy control women is reportedly $75 \%$ of lean and $95 \%$ of overweight women (weight status according to WHO criteria) [1]. IR both promotes and interacts with hyperandrogenemia, which affects the function of the hypothalamic-pituitary-ovarian axis and causes abnormal follicular development [2]. 
medRxiv preprint doi: https://doi.org/10.1101/2022.01.31.22270217; this version posted February 2, 2022. The copyright holder for this preprint (which was not certified by peer review) is the author/funder, who has granted medRxiv a license to display the preprint in It is made available under a CC-BY 4.0 International license.

67 Additionally, regardless of age, gestational diabetes mellitus, impaired glucose tolerance, and type 2 diabetes are all significantly more prevalent in patients with PCOS. Some studies have found that improving IR and reducing hyperinsulinemia can reduce systemic androgen concentrations and improve some characteristics of PCOS [3]. Metformin is often recommended to adult women or adolescents with PCOS or women with BMI $>25 \mathrm{~kg} / \mathrm{m}^{2}$ for management of weight and metabolic disorders [4]. However, the mechanism underlying metformin's effects on PCOS-IR is not yet fully understood and it causes adverse effects, particularly diarrhea and nausea, in up to $25 \%$ of patients [5]. Thus, metformin has limitations related to adverse effects and patient compliance. There is therefore a need for inexpensive and easily administered treatments with few adverse effects. Correlation meta-analysis has shown that acupuncture has a beneficial effect on IR and fewer adverse reactions than other treatments $[6,7]$. A recent meta-analysis also found that acupuncture can improve IR in patients with PCOS [8]. However, this evidence is inadequate because of the poor quality and methodology of the included studies. In addition, these authors did not determine whether acupuncture has advantages over metformin in the treatment of PCOS-IR. In the present study, we systematically reviewed data from recent studies, aiming to provide clarity concerning the role of acupuncture in treatment of PCOS-IR, especially compared with metformin. evaluate the efficacy and safety of acupuncture in improving PCOS-IR by assessing the following key outcomes: homeostasis model assessment of insulin resistance (HOMA- 
medRxiv preprint doi: https://doi.org/10.1101/2022.01.31.22270217; this version posted February $2,2022$. The copyright holder for this preprint (which was not certified by peer review) is the author/funder, who has granted medRxiv a license to display the preprint in It is made available under a CC-BY 4.0 International license.

89 IR), fasting blood glucose (FBG), 2-h postprandial blood glucose (2h-PBG), fasting

90 insulin (FINS), body mass index (BMI), and adverse events.

\section{Methods}

92 This analysis was performed strictly in accordance with the PRISMA statement [9] (see

93 S1 File). Additionally, this review was registered with PROSPERO at 94 http://www.crd.york.ac.uk/PROSPERO(CRD42021285851).

\subsection{Search strategy}

PubMed, Cochrane Library, and Embase databases were searched without language

restrictions from inception to 20 December 2021. We also searched Chinese databases, (VIP), and Wanfang databases. Additionally, only studies in Chinese databases that had

101 Moxibustion) were included. The search terms consisted of four parts: acupuncture

102 (acupuncture, electroacupuncture, and manual acupuncture), insulin resistance (insulin

103 resistance and insulin sensitivity), polycystic ovary syndrome (polycystic ovary

104 syndrome, polycystic ovarian syndrome and Stein-Leventhal syndrome), and

105 randomized controlled trial. Details of the search strategies are presented in S2 File.

106 Additionally, ClinicalTrials.gov and the Chinese Clinical Trial Register were 107 searched to identify ongoing or recently completed studies. 
medRxiv preprint doi: https://doi.org/10.1101/2022.01.31.22270217; this version posted February $2,2022$. The copyright holder for this preprint (which was not certified by peer review) is the author/funder, who has granted medRxiv a license to display the preprint in perpetuity

It is made available under a CC-BY 4.0 International license .

$110 \quad$ 2.2.1 Types of study All randomized controlled trials (RCTs) involving use of

111 acupuncture for treating PCOS-IR were included.

112 2.2.2 Types of participant Patients diagnosed with PCOS-IR or PCOS patients

113 with HOMA-IR $\geq 2.14$ [10], regardless of race, or educational and economic status,

114 were included.

$115 \quad$ 2.2.3 Types of intervention Interventions in the experimental group comprised

116 acupuncture or electroacupuncture either combined with medication or not. Controlled

117 interventions with sham acupuncture or metformin were included.

118 2.2.4 Types of outcome measure Studies that reported at least one clinical 119 outcome related to PCOS-IR were included. The primary outcome was HOMA-IR. The 120 secondary outcomes were FBG, 2h-PBG, FINS, BMI, and adverse events.

\subsection{Exclusion criteria}

2.3.1 Types of study Nonrandomized controlled trials, randomized crossover trials,

124 reviews, case reports, protocols, experimental animal articles were excluded.

2.3.2 Participants Participants with serious physical or mental disease were excluded.

2.3.3 Types of intervention We did not include trials in which non-penetrating

128 acupuncture (such as via laser stimulation, acupressure, or transcutaneous electrical

129 nerve stimulation) was used or in which other traditional Chinese medicine was

130 administered to the experimental group. RCTs that compared different forms of

131 acupuncture or herbal medicine were also excluded. 


\section{$133 \quad$ 2.4 Study identification and data extraction}

134 Two independent appraisers (Yu Liu and Jin-qun $\mathrm{Hu}$ ) assessed the eligibility of the

135 searched articles in accordance with the above criteria. The following data were

136 extracted independently from all included studies by two reviewers (Yu Liu and Ming

137 Chen): number of participants, age, interventions, intervention duration, change in

138 HOMA-IR (mean [SD]); change in FBG (mean [SD]); change in 2h-PBG (mean [SD]);

139 change in FINS (mean [SD]); change in BMI (mean [SD]), and number of participants

140 with any adverse events. Any disagreements regarding study identification and data

141 extraction were resolved by discussion and adjudication with a third investigator (Hua142 ying Fan).

\subsection{Quality assessment}

145 Two reviewers ( $\mathrm{Yu}$ Liu and Jin-qun $\mathrm{Hu}$ ) independently assessed the risk of bias of

146 RCTs using the Cochrane Collaboration's "risk of bias" tool, which is based on the

147 following six separate domains: random sequence generation (selection bias),

148 allocation concealment (selection bias), blinding of participants and personnel

149 (performance bias), blinding of outcome assessment (detection bias), incomplete

150 outcome data (attrition bias), selective reporting (reporting bias), and other bias. The

151 assessments were categorized into three levels of bias: low risk, high risk, or unclear

152 risk. For example, if the investigators described a random component in the sequence

153 generation process, such as using a computer random number generator or coin tossing, 
medRxiv preprint doi: https://doi.org/10.1101/2022.01.31.22270217; this version posted February $2,2022$. The copyright holder for this preprint (which was not certified by peer review) is the author/funder, who has granted medRxiv a license to display the preprint in perpetuity.

It is made available under a CC-BY 4.0 International license.

154 "low risk" would be allocated for the domain of random sequence generation.

155 Disagreements were resolved by a third investigator (Hua-ying Fan).

156 We also used Grading of Recommendations Assessment, Development, and 157 Evaluation (GRADE) to assess the quality of evidence, using GRADEpro GOT online 158 software.

$160 \quad$ 2.6 Data synthesis

161 We assessed the effect and safety of acupuncture for treating PCOS-IR on the basis of 162 six outcomes: HOMA-IR, FBG, 2h-PBG, FINS, incidence of adverse events, and BMI.

163 We analyzed HOMA-IR, FBG, 2h-PBG, FINS, and BMI as continuous variables and 164 have reported absolute differences between arithmetic means before and after 165 interventions. Adverse events were treated as a categorical variable and the risk ratio 166 calculated.

167 We calculated pooled estimates of the mean differences (MD) in HOMA-IR, FBG, 168 2h-PBG, FINS, and BMI between intervention groups using a random-effects model 169 (DerSimonian-Laird method) to minimize additional uncertainty associated with inter170 study variability regarding the effects of different interventions. We also calculated 171 pooled risk ratio estimates for categorical outcomes with a random-effects model 172 (DerSimonian-Laird method).

173 We used the Cochran Q test to assess heterogeneity between studies. P values less 174 than 0.1 were considered to denote statistical significance. We also did $I^{2}$ testing to 175 assess the magnitude of heterogeneity between studies, values greater than $50 \%$ being 
medRxiv preprint doi: https://doi.org/10.1101/2022.01.31.22270217; this version posted February $2,2022$. The copyright holder for this preprint (which was not certified by peer review) is the author/funder, who has granted medRxiv a license to display the preprint in perpetuity.

It is made available under a CC-BY 4.0 International license .

176 regarded as indicative of moderate-to-high heterogeneity. If necessary, subgroup

177 analyses according to type of intervention were conducted. We used RevMan (version

178 5.4) for all statistical analyses.

$179 \quad 3$ Results

$180 \quad 3.1$ Search results

181 A flow chart of study selection is shown in Fig 1. Our preliminary search found a total

182 of 723 articles. Removing duplicate articles and reading the title and summary filters

183 left 62 full-text articles, 53 of which were excluded because they did not meet the

184 inclusion criteria. Two more articles were excluded because their data were unavailable

185 and we received no responses from the corresponding authors. Finally, seven studies

186 including 728 patients were included in this review.

Fig 1. Literature screening process and results.

\subsection{Description of included studies}

190 The seven eligible RCTs including 728 patients were conducted in China. Three of

191 them were listed in English databases and four in Chinese databases. All participants

192 had been diagnosed with PCOS in accordance with the Rotterdam criteria and had

193 HOMA-IR greater than 2.14, enabling diagnosis of IR [10]. The patients had a mean

194 baseline HOMA-IR of 4.02 (range 2.37-5.06) and mean baseline BMI of $27.18 \mathrm{~kg} / \mathrm{m}^{2}$

195 (22.4-29.35). Electroacupuncture was compared with sham acupuncture in two studies

196 [11,12], acupuncture combined with medication was compared with medication alone 
medRxiv preprint doi: https://doi.org/10.1101/2022.01.31.22270217; this version posted February 2, 2022. The copyright holder for this preprint (which was not certified by peer review) is the author/funder, who has granted medRxiv a license to display the preprint in It is made available under a CC-BY 4.0 International license .

197 in two studies $[13,14]$, and acupuncture was compared with metformin in three studies

198 [15-17]. Table 1 summarizes the basic characteristics of these studies.

199 Table 1. Characteristics of included studies.

\begin{tabular}{|c|c|c|c|c|c|c|c|c|}
\hline \multirow[t]{2}{*}{ Study ID } & \multirow{2}{*}{$\begin{array}{c}\text { Sample } \\
\text { size } \\
\text { (TG/CG) }\end{array}$} & \multicolumn{2}{|c|}{ Intervention } & \multirow{2}{*}{$\begin{array}{l}\text { Duration of } \\
\text { intervention }\end{array}$} & \multirow{2}{*}{$\begin{array}{l}\text { Mean } \\
\text { age } \\
\text { (years) }\end{array}$} & \multirow{2}{*}{$\begin{array}{c}\text { Mean } \\
\text { BMI } \\
\left(\mathrm{kg} / \mathrm{m}^{2}\right)\end{array}$} & \multirow{2}{*}{$\begin{array}{c}\text { Mean } \\
\text { HOMA- } \\
\text { IR }\end{array}$} & \multirow[t]{2}{*}{ Outcomes } \\
\hline & & TG & CG & & & & & \\
\hline Dong,2021[11] & $27 / 27$ & EA & SA & 16 weeks & 22.8 & 22.4 & 2.37 & (1)(2) (4) \\
\hline $\mathrm{Gu}, 2019[12]$ & $39 / 39$ & EA & SA & 32 times & 27.8 & 27.6 & 5.06 & (1) (2) (3) (4) 6 \\
\hline $\mathrm{Li}, 2014[13]$ & $53 / 51$ & $\mathrm{~A}+\mathrm{M}$ & $\mathrm{SA}+\mathrm{M}$ & 6 months & 26.1 & 29.35 & 3.75 & (1) (2) (4) 5 \\
\hline Мао,2021[14] & $54 / 54$ & $\mathrm{EA}+\mathrm{M}+\mathrm{E}$ & $\mathrm{M}+\mathrm{E}$ & $3 \mathrm{MC}$ & $\begin{array}{c}\text { Not } \\
\text { available }\end{array}$ & 28.32 & 3.83 & (1) 5 \\
\hline Wen,2021[15] & $114 / 114$ & $\mathrm{EA}+\mathrm{P}$ & $\mathrm{SA}+\mathrm{M}$ & 4 months & 27.7 & 26.15 & 4.47 & (1) (2) (4) 6 \\
\hline $\mathrm{Yu}, 2020[16]$ & $36 / 34$ & EA & M & 3 months & 30.5 & $\begin{array}{c}\text { Not } \\
\text { available }\end{array}$ & 4.81 & (1)6 \\
\hline Zheng,2013[17] & $43 / 43$ & A & M & 6 months & 25.7 & 29.25 & 3.85 & (1)(2) (4) (5) \\
\hline
\end{tabular}

200 A, acupuncture; CG, control group; E, ethinylestradiol and cyproterone acetate tablets;

201 EA, electroacupuncture; M, metformin; MC, menstrual cycle; P, placebo; SA, sham

202 acupuncture; TG, treatment group; (1), HOMA-IR; (2), FBG; (3), 2h-PBG; (4), FINS;

203 (5), BMI; 6), adverse events. 
medRxiv preprint doi: https://doi.org/10.1101/2022.01.31.22270217; this version posted February 2, 2022. The copyright holder for this preprint (which was not certified by peer review) is the author/funder, who has granted medRxiv a license to display the preprint in It is made available under a CC-BY 4.0 International license.

206 The participants were randomized using a random number table or computer program

207 in all seven studies. Assessment of allocation was described in three articles $[11,15,17]$.

208 For blinding, three trials $[11,13,15]$ were classified as "low risk" and the others as

209 "unclear risk". Three articles $[11,15,16]$ stated explicitly that third-party researchers

210 processed the data. Four studies[11,12,15,16] reported loss to follow-up. There was

211 attrition bias in two of these studies [11,15] as a result of differences in the proportion

212 of missing outcome data between the experimental and comparison groups. The other

213 three trials had a low risk of attrition bias, having reported that no participants dropped

214 out or were excluded from the primary analysis. Details of the assessments are shown 215 in Figs 2 and 3.

216 Fig 2. Assessment of risk biases of the included studies.

217 Fig 3. Assessment of risk biases of the included studies.

\subsection{Meta-analysis of primary outcomes}

220 A pooled meta-analysis analysis of the seven trials found no statistically significant

221 differences in changes in HOMA-IR (MD, $-0.33 ; 95 \% \mathrm{CI},-0.87$ to $0.22 ; \mathrm{P}=0.24$; Fig

222 4) between the two groups, with statistically significant heterogeneity $\left(\mathrm{P}<0.1 ; I^{2}=82 \%\right)$.

223 To further analyze heterogeneity, we performed subgroup analysis of different

224 interventions to more accurately examine the effects of acupuncture. Sensitivity

225 analysis comparing acupuncture treatment with metformin or sham acupuncture

226 identified no significant differences (MD, 0.04; 95\% CI, -0.7 to 0.78 ; $\mathrm{P}=0.92$; Fig 4)

227 (MD, $-0.64 ; 95 \% \mathrm{CI},-2.2$ to $0.93 ; \mathrm{P}=0.42$; Fig 4). However, comparison of a 
medRxiv preprint doi: https://doi.org/10.1101/2022.01.31.22270217; this version posted February $2,2022$. The copyright holder for this preprint (which was not certified by peer review) is the author/funder, who has granted medRxiv a license to display the preprint in It is made available under a CC-BY 4.0 International license.

228 combination of acupuncture and medication with medication alone showed a greater

229 mean reduction in HOMA-IR with the former $(\mathrm{MD},-0.63 ; 95 \% \mathrm{CI},-1.12$ to -0.14 ;

$230 \mathrm{P}=0.01$; Fig 4).

231 Fig 4. Comparison of changes in HOMA-IR according to intervention.

\subsection{Meta-analysis of secondary outcomes}

234 3.5.1 FBG Pooled analysis of the five studies that assessed changes in participants'

235 FBG after treatment showed a trend to improvement in FBG that was not statistically

236 significant $(\mathrm{MD},-0.43 ; 95 \% \mathrm{CI},-0.88$ to $0.03 ; \mathrm{P}=0.07$; Fig 5), with statistically

237 significant heterogeneity $\left(\mathrm{P}<0.1 ; I^{2}=86 \%\right)$.

238 Forest plots generated in further sensitivity analysis showed no significant difference

239 between acupuncture and metformin $(\mathrm{MD},-0.17 ; 95 \% \mathrm{CI},-0.4$ to $0.05 ; \mathrm{P}=0.13$; Fig

240 5). Additionally, combination treatment showed no benefit over medication alone (MD,

$241-0.4 ; 95 \% \mathrm{CI},-1.03$ to $0.23 ; \mathrm{P}=0.21 ;$ Fig 5$)$.

242 Fig 5. Comparison of changes in FBG according to intervention.

243 3.5.2 2h-PBG Two studies ( $\mathrm{N}=162$ participants) assessed changes in $2 \mathrm{~h}-\mathrm{PBG}$ at the

244 end of the intervention. Pooling the data of these studies showed no significant

245 difference in mean reduction of $2 \mathrm{~h}-\mathrm{PBG}$ between acupuncture and other treatments

246 (MD, $-0.40 ; 95 \% \mathrm{CI},-0.90$ to $0.10 ; \mathrm{P}=0.12$; Fig 6 ), without between-study

247 heterogeneity.

248 Fig 6. Comparison of changes in 2h-PBG according to intervention. 
medRxiv preprint doi: https://doi.org/10.1101/2022.01.31.22270217; this version posted February 2, 2022. The copyright holder for this preprint (which was not certified by peer review) is the author/funder, who has granted medRxiv a license to display the preprint in It is made available under a CC-BY 4.0 International license.

3.5.3 FINS Five studies ( $N=502$ participants) assessed changes in participants' FINS after treatment. Pooled analysis of these studies' findings showed that acupuncture was not more effective than other treatments regarding mean reduction in FINS (MD, -0.65 ; $95 \% \mathrm{CI},-2.18$ to $0.89 ; \mathrm{P}=0.41 ;$ Fig 7 ), with no significant between-study heterogeneity $\left(\mathrm{P}>0.1 ; I^{2}=37 \%\right)$.

\section{Fig 7 Comparison of changes in FINS according to intervention.}

3.5.4 BMI. Six studies assessed changes in participants' BMI after treatment. Analysis of pooled data of these studies showed that acupuncture was associated with a greater reduction in weight than other treatment $(\mathrm{MD},-1.21 ; 95 \% \mathrm{CI},-2.41$ to -0.02 ; $\mathrm{P}=0.05$; Fig 8), with statistically significant heterogeneity $\left(\mathrm{P}<0.1 ; I^{2}=88 \%\right)$.

Sensitivity analysis revealed no statistically significant difference in changes in BMI between acupuncture and metformin $(\mathrm{MD},-0.75 ; 95 \% \mathrm{CI},-3.33$ to $1.82 ; \mathrm{P}=0.57$;

Fig 8). However, a combination of acupuncture and medication achieved a greater mean reduction in $\mathrm{BMI}$ than did medication alone $\mathrm{MD},-1.36 ; 95 \% \mathrm{CI},-2.07$ to -0.66 ; $\mathrm{P}<0.01$; Fig 8).

Fig 8. Comparison of changes in BMI according to intervention.

3.5.5 Adverse events Five of the studies reported adverse events. Three of these studies compared acupuncture with metformin, one compared combined treatment with acupuncture and medication with medication alone and one compared electroacupuncture with sham acupuncture. One [16] reported $29.4 \%$ cases of nausea, emesis, diarrhea, and loss of appetite in the control group and $11.1 \%$ of subcutaneous bruising and hematoma in the experimental group. One [15] reported $87.7 \%$ adverse 
medRxiv preprint doi: https://doi.org/10.1101/2022.01.31.22270217; this version posted February 2, 2022. The copyright holder for this preprint (which was not certified by peer review) is the author/funder, who has granted medRxiv a license to display the preprint in It is made available under a CC-BY 4.0 International license.

271 gastrointestinal events in the control group and $14.9 \%$ cases of subcutaneous bruising

272 and hematoma in the experimental group. One [17] reported $48.8 \%$ adverse effects in

273 the control group and none in the experimental group. One [13] reported $43.1 \%$ cases

274 of nausea, emesis, diarrhea, and loss of appetite in the control group and $34 \%$ adverse

275 events in the experimental group. Most adverse events were digestive tract reactions or

276 subcutaneous bruising and hematoma and resolved quickly. There were no distressing

277 symptoms or liver or kidney injury. Table 2 displays the reported details.

278 Table 2. Reported adverse events.

\begin{tabular}{|c|c|c|c|c|c|c|c|c|}
\hline \multirow[t]{2}{*}{ Study ID } & \multicolumn{2}{|c|}{ Sample size } & \multicolumn{2}{|c|}{ Intervention } & \multicolumn{2}{|c|}{$\begin{array}{l}\text { Nausea, emesis, } \\
\text { diarrhea, and loss } \\
\text { of appetite }\end{array}$} & \multicolumn{2}{|c|}{$\begin{array}{l}\text { Subcutaneous } \\
\text { bruising and } \\
\text { hematoma }\end{array}$} \\
\hline & $\mathrm{TG}$ & $\mathrm{CG}$ & TG & CG & $\mathrm{TG}$ & $\mathrm{CG}$ & $\mathrm{TG}$ & $\mathrm{CG}$ \\
\hline $\mathrm{Gu}, 2019[12]$ & 39 & 39 & EA & SA & - & - & 0 & 0 \\
\hline $\mathrm{Li}, 2014[13]$ & 53 & 51 & $\mathrm{~A}+\mathrm{M}$ & $\mathrm{SA}+\mathrm{M}$ & 18 & 22 & - & - \\
\hline Wen,2021[15] & 114 & 114 & $\mathrm{EA}+\mathrm{P}$ & $\mathrm{SA}+\mathrm{M}$ & - & 100 & 17 & - \\
\hline $\mathrm{Yu}, 2020[16]$ & 36 & 34 & EA & M & - & 10 & 4 & - \\
\hline Zheng,2013[17] & 43 & 43 & $\mathrm{~A}$ & M & - & 21 & 0 & - \\
\hline
\end{tabular}

279 A, acupuncture; CG, control group; EA, electroacupuncture; M, metformin; P,

280 placebo; SA, sham acupuncture; TG, treatment group. 
medRxiv preprint doi: https://doi.org/10.1101/2022.01.31.22270217; this version posted February 2, 2022. The copyright holder for this preprint (which was not certified by peer review) is the author/funder, who has granted medRxiv a license to display the preprint in perpetuity.

It is made available under a CC-BY 4.0 International license .

283 The quality of evidence assessed using the GRADE system varied from very low to

284 low. According to this system, FINS had a low evidence level because the means of

285 assessing allocation was not described, and the upper or lower confidence limits crossed

286 an effect size of 0.5 in both directions. Further, HOMA-IR, FBG, 2h-PBG, and BMI

287 had very low evidence levels. Details of assessment are shown in Table 3.

288 Table 3. Assessment according to GRADE system.

\begin{tabular}{|c|c|c|c|c|c|c|c|c|c|c|}
\hline \multirow{2}{*}{$\begin{array}{c}\text { Outco } \\
\text { me }\end{array}$} & \multicolumn{6}{|c|}{ Certainty assessment } & \multicolumn{2}{|c|}{ Effect } & \multirow[b]{2}{*}{$\begin{array}{c}\text { Num } \\
\text { ber of } \\
\text { patie } \\
\text { nts } \\
\text { (studi } \\
\text { es) }\end{array}$} & \multirow[b]{2}{*}{$\begin{array}{l}\text { Certa } \\
\text { inty } \\
\text { of the } \\
\text { evide } \\
\text { nce } \\
\text { (GRA } \\
\text { DE) }\end{array}$} \\
\hline & $\begin{array}{c}\text { Stud } \\
y \\
\text { desi } \\
\text { gn }\end{array}$ & $\begin{array}{c}\text { Risk of } \\
\text { bias }\end{array}$ & $\begin{array}{c}\text { Inconsis } \\
\text { tency }\end{array}$ & $\begin{array}{c}\text { Indirec } \\
\text { tness }\end{array}$ & $\begin{array}{c}\text { Imprecis } \\
\text { ion }\end{array}$ & $\begin{array}{l}\text { Other } \\
\text { consider } \\
\text { ations }\end{array}$ & $\begin{array}{l}\text { Relative } \\
(95 \% \mathrm{CI})\end{array}$ & Absolute & & \\
\hline $\begin{array}{l}\text { HOMA } \\
\text {-IR }\end{array}$ & $\mathrm{RCT}$ & $\begin{array}{c}\text { serious } \\
\text { a }\end{array}$ & $\begin{array}{c}\text { very } \\
\text { serious b }\end{array}$ & $\begin{array}{c}\text { not } \\
\text { serious }\end{array}$ & serious $^{\mathrm{c}}$ & none & - & $\begin{array}{l}\text { MD } 0.33 \text { lower } \\
(0.87 \text { lower to } \\
0.22 \text { higher })\end{array}$ & $\begin{array}{c}669 \\
(7 \\
\text { RCTs } \\
\quad)\end{array}$ & $\begin{array}{l}\oplus \ominus \\
\ominus \ominus \\
\text { Very } \\
\text { low }\end{array}$ \\
\hline FBG & RCT & $\begin{array}{c}\text { serious } \\
\text { a }\end{array}$ & $\begin{array}{c}\text { very } \\
\text { serious } b\end{array}$ & $\begin{array}{c}\text { not } \\
\text { serious }\end{array}$ & serious $^{c}$ & none & - & $\begin{array}{l}\text { MD } 0.43 \text { lower } \\
\text { (0.88 lower to } \\
0.03 \text { higher) }\end{array}$ & $\begin{array}{c}501 \\
(5 \\
\text { RCTs } \\
\quad)\end{array}$ & $\begin{array}{l}\oplus \ominus \\
\ominus \ominus \\
\text { Very } \\
\text { low }\end{array}$ \\
\hline
\end{tabular}


medRxiv preprint doi: https://doi.org/10.1101/2022.01.31.22270217; this version posted February $2,2022$. The copyright holder for this preprint (which was not certified by peer review) is the author/funder, who has granted medRxiv a license to display the preprint in

\begin{tabular}{|c|c|c|c|c|c|c|c|c|c|c|}
\hline $\begin{array}{l}\text { 2h- } \\
\text { PBG }\end{array}$ & RCT & $\begin{array}{c}\text { serious } \\
\text { a }\end{array}$ & $\begin{array}{c}\text { not } \\
\text { serious }\end{array}$ & $\begin{array}{c}\text { not } \\
\text { serious }\end{array}$ & $\begin{array}{c}\text { very } \\
\text { serious }{ }^{d}\end{array}$ & none & - & $\begin{array}{l}\text { MD } 0.4 \text { lower } \\
\text { (0.9 lower to } 0.1 \\
\text { higher) }\end{array}$ & $\begin{array}{c}162 \\
(2 \\
\text { RCTs } \\
\quad)\end{array}$ & $\begin{array}{l}\oplus \ominus \\
\ominus \ominus \\
\text { Very } \\
\text { low }\end{array}$ \\
\hline FINS & RCT & $\begin{array}{c}\text { serious } \\
\mathrm{a}\end{array}$ & $\begin{array}{c}\text { not } \\
\text { serious }\end{array}$ & $\begin{array}{c}\text { not } \\
\text { serious }\end{array}$ & serious $^{c}$ & none & - & $\begin{array}{l}\text { MD } 0.65 \text { lower } \\
\text { (2.18 lower to } \\
0.89 \text { higher) }\end{array}$ & $\begin{array}{r}502 \\
(5 \\
\text { RCTs }\end{array}$ & $\begin{array}{l}\oplus \oplus \\
\ominus \ominus \\
\text { low }\end{array}$ \\
\hline BMI & RCT & $\begin{array}{c}\text { serious } \\
\text { a }\end{array}$ & $\begin{array}{c}\text { very } \\
\text { serious }{ }^{b}\end{array}$ & $\begin{array}{c}\text { not } \\
\text { serious }\end{array}$ & $\begin{array}{c}\text { not } \\
\text { serious }\end{array}$ & none & - & $\begin{array}{l}\text { MD } 1.21 \text { lower } \\
\text { (2.41 lower to } \\
0.02 \text { lower) }\end{array}$ & $\begin{array}{c}612 \\
(6 \\
\text { RCTs } \\
\quad)\end{array}$ & $\begin{array}{l}\oplus \ominus \\
\ominus \ominus \\
\text { Very } \\
\text { low }\end{array}$ \\
\hline
\end{tabular}

289 a The means of assessing allocation is not described.

$290{ }^{\mathrm{b}} I^{2} \geq 75 \%$ in the Q statistics indicates serious inconsistency in the meta-analysis.

$291{ }^{\mathrm{c}}$ The upper or lower confidence limit has crossed an effect size of 0.5 in either direction.

$292 \mathrm{~d}$ Total cohort is less than 400, and effect size is considered small; the upper or lower

293 confidence limit has crossed an effect size of 0.5 in either direction.

\section{Discussion}

\section{Main findings}

296 The purpose of this review was to evaluate the effectiveness of acupuncture for IR in

297 patients with PCOS. We found acupuncture to be significantly associated with greater

298 loss of body weight (based on very low-certainty evidence) than other treatments. 
medRxiv preprint doi: https://doi.org/10.1101/2022.01.31.22270217; this version posted February $2,2022$. The copyright holder for this preprint (which was not certified by peer review) is the author/funder, who has granted medRxiv a license to display the preprint in It is made available under a CC-BY 4.0 International license.

299 However, we identified no significant differences for the other studied outcomes, 300 namely FINS (based on low-certainty evidence), and HOMA-IR, FBG, and 2h-PBG

301 (all based on very low-certainty evidence). Although acupuncture is not more effective 302 than metformin in improving IR, it does not cause nausea, emesis, or diarrhea, and any 303 subcutaneous hematoma will resolve quickly. Furthermore, we found that, compared 304 with medication alone, a combination of acupuncture and medication yields 305 improvements in HOMA-IR and BMI with fewer gastrointestinal adverse events. 306 Therefore, our findings indicate that acupuncture is a promising adjuvant strategy for 307 treating PCOS-IR.

308 The cause of PCOS is unknown. However, it is strongly associated with IR and the 309 risk of type 2 diabetes in PCOS patients is 5-10 times higher than that in the general 310 population [18]. Clinical and experimental evidence has shown that acupuncture is an 311 acceptable, adverse effect-free alternative or complement to pharmacological induction 312 of ovulation in women with PCOS and may also relieve other symptoms [19]. There is 313 also evidence that acupuncture can be an insulin sensitizer and may therefore contribute 314 to controlling obesity and type 2 diabetes [20,21]. Acupuncture ameliorates IR through 315 enhancing autophagy [22], affecting insulin receptor signal transduction, and increased 316 expression of insulin receptor substrate in the endometrium in a PCOS-like rat model $317 \quad[23,24]$

\section{Limitations}


medRxiv preprint doi: https://doi.org/10.1101/2022.01.31.22270217; this version posted February $2,2022$. The copyright holder for this preprint (which was not certified by peer review) is the author/funder, who has granted medRxiv a license to display the preprint in perpetuity

It is made available under a CC-BY 4.0 International license .

320 First, most studies examined were small and some of them described the specifics of

321 assessing allocation and blinding poorly. Their quality was therefore mediocre. Besides,

322 according to the GRADE system, only one outcome was based on low-certainty

323 evidence, the other four outcomes being based on very low-certainty evidence. Second,

324 these studies lack follow-up data, hindering assessment of the long-term efficacy of

325 acupuncture for PCOS-IR.

326 Finally, there was heterogeneity in some outcomes. We accordingly performed 327 subgroup analyses; however, the likelihood of false negative and false positive findings 328 regarding significance increase rapidly with increasing numbers of subgroup analyses.

329 Of note, metabolic syndrome has varying clinical manifestations and biochemical 330 characteristics, age distribution, and abnormal glucose metabolism. Further, there were 331 differences in the details of the interventions, severity of disease, dosage of metformin, 332 and acupuncture protocols between studies.

\section{Implications for further clinical research}

335 Being a safe and simple treatment modality, acupuncture could be a good alternative or

336 adjuvant therapy for PCOS-IR, especially for overweight patients. Because it has fewer 337 adverse effects than metformin, patient acceptance and compliance may be higher.

338 Regardless of age, the prevalences of gestational diabetes mellitus, impaired glucose 339 tolerance, and type 2 diabetes are significantly greater in individuals with PCOS than 340 in those without it. The risk is not related to obesity but is increased by obesity [4].

341 Successful treatment of obesity therefore reduces IR [25]. It is gratifying that 
medRxiv preprint doi: https://doi.org/10.1101/2022.01.31.22270217; this version posted February $2,2022$. The copyright holder for this preprint (which was not certified by peer review) is the author/funder, who has granted medRxiv a license to display the preprint in It is made available under a CC-BY 4.0 International license.

342 acupuncture is significantly more effective at achieving weight loss than other

343 treatments. Unfortunately, the long-term effects of acupuncture are still unknown.

344 Additional long-term follow-up studies are needed to clarify the role of acupuncture in 345 the treatment of PCOS-IR.

346 In addition, some comparative studies of acupuncture and sham acupuncture have

347 found that these two interventions achieve equivalent results. A review of the designs

348 of these studies revealed that sham acupuncture involved needling non-acupuncture or

349 irrelevant acupuncture points, or superficial needling. However, insertion of a needle

350 into a recognized acupuncture or non-acupuncture point can produce a physiological

351 effect, partly by activating the pain inhibiting system in the spinal cord and diffuse

352 noxious inhibitory controls [26-29]. In addition, sham acupuncture applied at non-

353 acupuncture points may serve as an active control because acupoint areas can be

354 enlarged by increased expression of nociceptive substances in individuals with painful

355 conditions [30]. It has therefore been suggested that more research into applying non-

356 penetrating sham acupuncture at non-acupuncture points is necessary [31]. This would

357 avoid segmental analgesia and minimize any physiological effect in the sham 358 acupuncture group.

\section{Conclusions}

362 This review of seven RCTs shows that acupuncture can reduce body weight 363 significantly in individuals with PCOS-IR and that, while not being more effective than 
medRxiv preprint doi: https://doi.org/10.1101/2022.01.31.22270217; this version posted February $2,2022$. The copyright holder for this preprint (which was not certified by peer review) is the author/funder, who has granted medRxiv a license to display the preprint in perpetuity.

It is made available under a CC-BY 4.0 International license.

364 metformin, it has fewer adverse effects. Additionally, combination treatment with

365 acupuncture and medication more effectively improves HOMA-IR and BMI, with less

366 gastrointestinal adverse events, than medication alone. Acupuncture may be an

367 effective adjuvant strategy for improving PCOS-IR. However, the evidence for this

368 conclusion is based on only a few studies with obvious limitations related to both

369 sample size and methodology. Further large-scale, long-term RCTs with strict

370 methodological standards are justified.

372 Acknowledgment

373 We thank Dr Trish Reynolds, MBBS, FRACP, from Liwen Bianji (Edanz)

374 (www.liwenbianji.cn/), for editing the English text of a draft of this manuscript.

\section{References}

377 1. Stepto NK, Cassar S, Joham AE, Hutchison SK, Harrison CL, Goldstein RF, et al. Women with polycystic ovary syndrome have intrinsic insulin resistance on euglycaemichyperinsulaemic clamp. Hum Reprod. 2013; 28:777-84. PMID: 23315061

2. Rosenfield RL, Ehrmann DA. The Pathogenesis of Polycystic Ovary Syndrome (PCOS): The Hypothesis of PCOS as Functional Ovarian Hyperandrogenism Revisited. Endocr Rev. 2016; ovary syndrome. Endocr Rev. 2003; 24:633-67. PMID: 14570747 
medRxiv preprint doi: https://doi.org/10.1101/2022.01.31.22270217; this version posted February 2, 2022. The copyright holder for this preprint (which was not certified by peer review) is the author/funder, who has granted medRxiv a license to display the preprint in It is made available under a CC-BY 4.0 International license.

385 4. Teede HJ, Misso ML, Costello MF, Dokras A, Laven J, Moran L, et al. Recommendations from the international evidence-based guideline for the assessment and management of

5. Flory J, Lipska K. Metformin in 2019. JAMA. 2019; 321:1926-7. PMID: 31009043

6. Song Ai-Qun, Zhang Yang-Pu, Chen Rui, Liang Feng-Xia. Is Acupuncture Effective for Improving Insulin Resistance? A Systematic Review and Meta-analysis. Curr Med Sci. 2018;

7. Wu Liqun, Chen Xiaokun, Liu Yun, Lan Jiao, Wu Chunxiao, Li Zhixing, et al. Role of acupuncture in the treatment of insulin resistance: A systematic review and meta-analysis.

8. Zheng R, Qing P, Han M, Song J, Hu M, Ma H, et al. The Effect of Acupuncture on Glucose systematic reviews and meta-analyses: the PRISMA statement. BMJ. 2009;339: b2535. PMID: 19622551 tolerance in Chinese women with polycystic ovary syndrome. Hum Reprod. 2006; 21:2027- 
medRxiv preprint doi: https://doi.org/10.1101/2022.01.31.22270217; this version posted February $2,2022$. The copyright holder for this preprint (which was not certified by peer review) is the author/funder, who has granted medRxiv a license to display the preprint in perpetuity.

It is made available under a CC-BY 4.0 International license.

405 11. Dong H-X, Wang Q, Wang Z, Wu X-K, Cheng L, Zhou Z-M, et al. Impact of Low Frequency Electro-acupuncture on Glucose and Lipid Metabolism in Unmarried PCOS Women: A

12. Gu Y, Xu X-F, He X-Y. Effect of acupuncture on improving glucose and lipid metabolism disorder in polycystic ovary syndrome. Shizhen national medicine. 2019; 30:2431-3.

13. Li L, Mo H, Wen B, Zhang J, Li Y, Chen W-F, et al. Clinical study on acupuncture combined with metformin in the treatment of infertility with obese polycystic ovary syndrome. Chinese Journal of traditional Chinese Medicine. 2014; 29:2115-9.

14. Mao M-Y, Lin L-C. Clinical effect of Tongyuan acupuncture on polycystic ovary syndrome of spleen deficiency and phlegm dampness type. Journal of Guangzhou University of traditional Chinese Medicine. 2021; 38:2138-45.

15. Wen Q, Hu M, Lai M, Li J, Hu Z, Quan K, et al. Effect of acupuncture and metformin on insulin sensitivity in women with polycystic ovary syndrome and insulin resistance: a threearmed randomized controlled trial. Hum Reprod. 2021; deab272. PMID: 28274268

16. Yu L-Q, Cao L-Y, Xie J, Shi Y, Zhou L-Y, He T-F, et al. Effect and mechanism of Electroacupuncture on insulin resistant polycystic ovary syndrome. Chinese acupuncture. acupuncture for patients with obesity-type polycystic ovary syndrome: A randomized controlled trial. J. Altern. Complement. Med. 2013; 19:740-5. PMID: 23676106 
medRxiv preprint doi: https://doi.org/10.1101/2022.01.31.22270217; this version posted February $2,2022$. The copyright holder for this preprint (which was not certified by peer review) is the author/funder, who has granted medRxiv a license to display the preprint in It is made available under a CC-BY 4.0 International license.

425 18. Ovalle F, Azziz R. Insulin resistance, polycystic ovary syndrome, and type 2 diabetes mellitus. Fertil Steril. 2002; 77:1095-105. PMID: 12057712

19. Stener-Victorin E, Jedel E, Mannerås L. Acupuncture in polycystic ovary syndrome: current experimental and clinical evidence. J Neuroendocrinol. 2008; 20:290-8. PMID: 18047551

20. Liang F, Koya D. Acupuncture: is it effective for treatment of insulin resistance? Diabetes Obes Metab. 2010; 12:555-69. PMID: 20590731

21. Firouzjaei A, Li G-C, Wang N, Liu W-X, Zhu B-M. Comparative evaluation of the therapeutic effect of metformin monotherapy with metformin and acupuncture combined therapy on weight loss and insulin sensitivity in diabetic patients. Nutr Diabetes. 2016;6: e209. PMID:

22. Peng Y, Guo L, Gu A, Shi B, Ren Y, Cong J, et al. Electroacupuncture alleviates polycystic

23. Zhang L, Li M, Yi W, Xu N-G, Sun J. Effect of acupuncture on PI3K p85 in skeletal muscle of rats with insulin resistance. New traditional Chinese Medicine. 2010; 42:112-114+148.

24. Lai M-H, Ma H-X, Li J, Song X-H, Liu H. Effects of Electroacupuncture on IRS1 and IRS2 mRNA expression and insulin sensitivity in endometrium of PCOS rats. Chinese Journal of integrated traditional Chinese and Western Medicine. 2016; 36:1082-6. 
medRxiv preprint doi: https://doi.org/10.1101/2022.01.31.22270217; this version posted February $2,2022$. The copyright holder for this preprint (which was not certified by peer review) is the author/funder, who has granted medRxiv a license to display the preprint in It is made available under a CC-BY 4.0 International license.

444 25. Greenfield JR, Campbell LV. Insulin resistance and obesity. Clin Dermatol. 2004; 22:28995. PMID: 15475228

26. Moffet HH. Sham acupuncture may be as efficacious as true acupuncture: a systematic review of clinical trials. J Altern Complement Med. 2009; 15:213-6. PMID: 19250001

27. Le Bars D, Villanueva L, Bouhassira D, Willer JC. Diffuse noxious inhibitory controls (DNIC) in animals and in man. Patol Fiziol Eksp Ter. 1992;55-65. PMID: 1303506

28. Cadden SW, Villanueva L, Chitour D, Le Bars D. Depression of activities of dorsal horn convergent neurones by propriospinal mechanisms triggered by noxious inputs; comparison pain inhibitory mechanism of nucleus raphe magnus. Pain. 1986; 24:383-96. PMID: 3485785

30. He W, Wang X-Y, Shi H, Bai W-Z, Cheng B, Su Y-S, et al. Cutaneous neurogenic inflammation in the sensitized acupoints induced by gastric mucosal injury in rats. BMC Complement Altern Med. 2017; 17:141. PMID: 28270193

31. Xu Shabei, Yu Lingling, Luo Xiang, Wang Minghuan, Chen Guohua, Zhang Qing, et al. Manual acupuncture versus sham acupuncture and usual care for prophylaxis of episodic migraine without aura: multicentre, randomised clinical trial. BMJ. 2020;368:m697. PMID: 
medRxiv preprint doi: https://doi.org/10.1101/2022.01.31.22270217; this version posted February 2, 2022. The copyright holder for this preprint (which was not certified by peer review) is the author/funder, who has granted medRxiv a license to display the preprint in

perpetuity.
It is made available under a CC-BY 4.0 International license .

463

464 Supporting information

465 S1 File. PRISMA Checklist

466 (DOC)

467 S2 File. Search strategies used in English databases

468 (DOC) 
Records identified through database searching $(\mathrm{n}=723)$

CNKI:342

Wangfang:235

VIP:54
PubMed:31

Embase: 38

Cochrane: 23

medR Kiv preprint doi: https://doi.org/10.1101/2022.01.31.22270217; this version posted February 2, 2022 The copyright holder for this

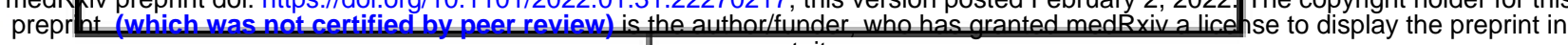
It is made available under a CC-BY 4.0 International license .

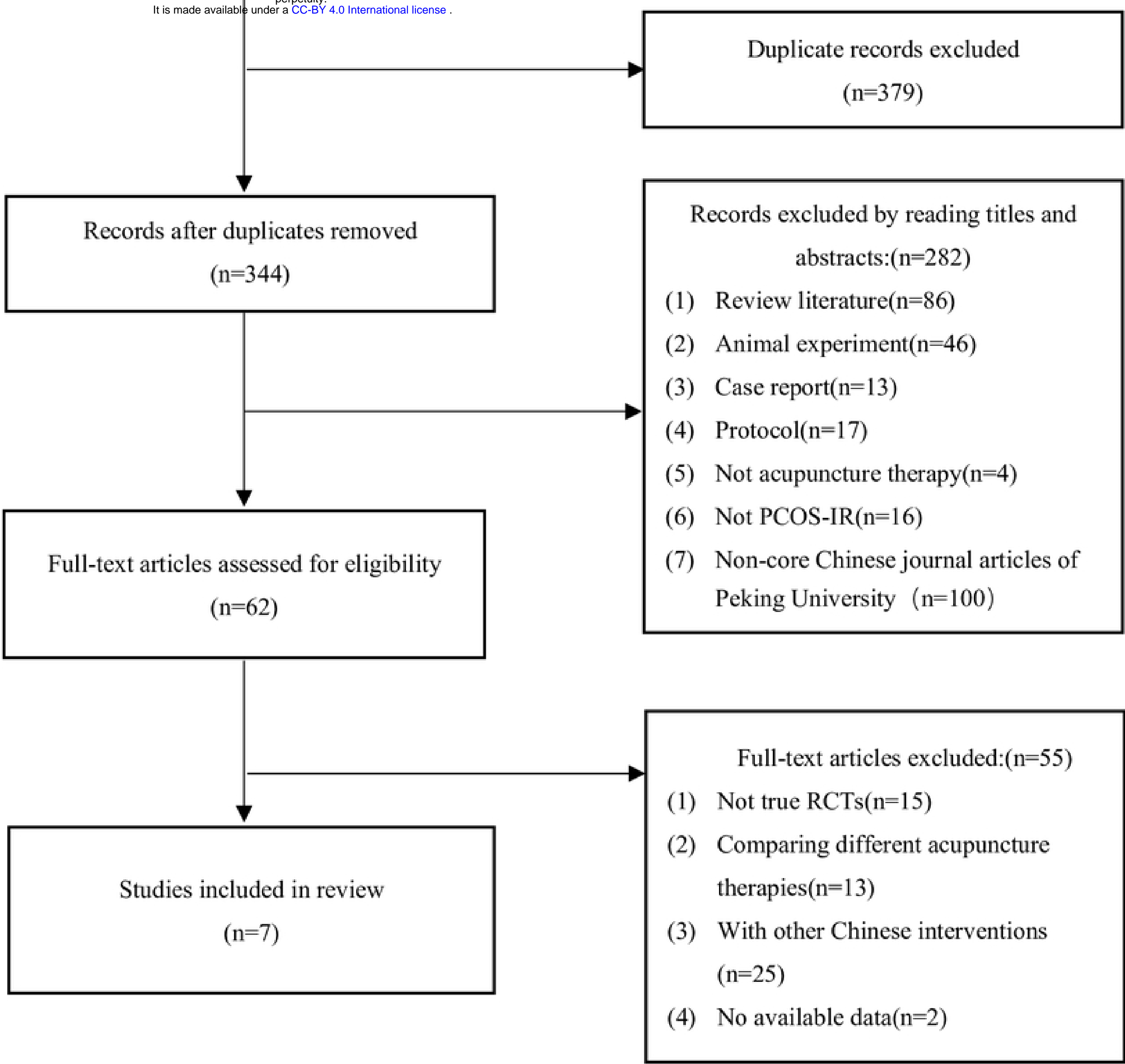

Fig1 
Random sequence generation (selection bias)

Allocation concealment (selection bias)

Blinding of participants and personnel (performance bias)

Blinding of outcome assessment (detection bias)

Incomplete outcome data (attrition bias)

Selective reporting (reporting bias)

Other bias

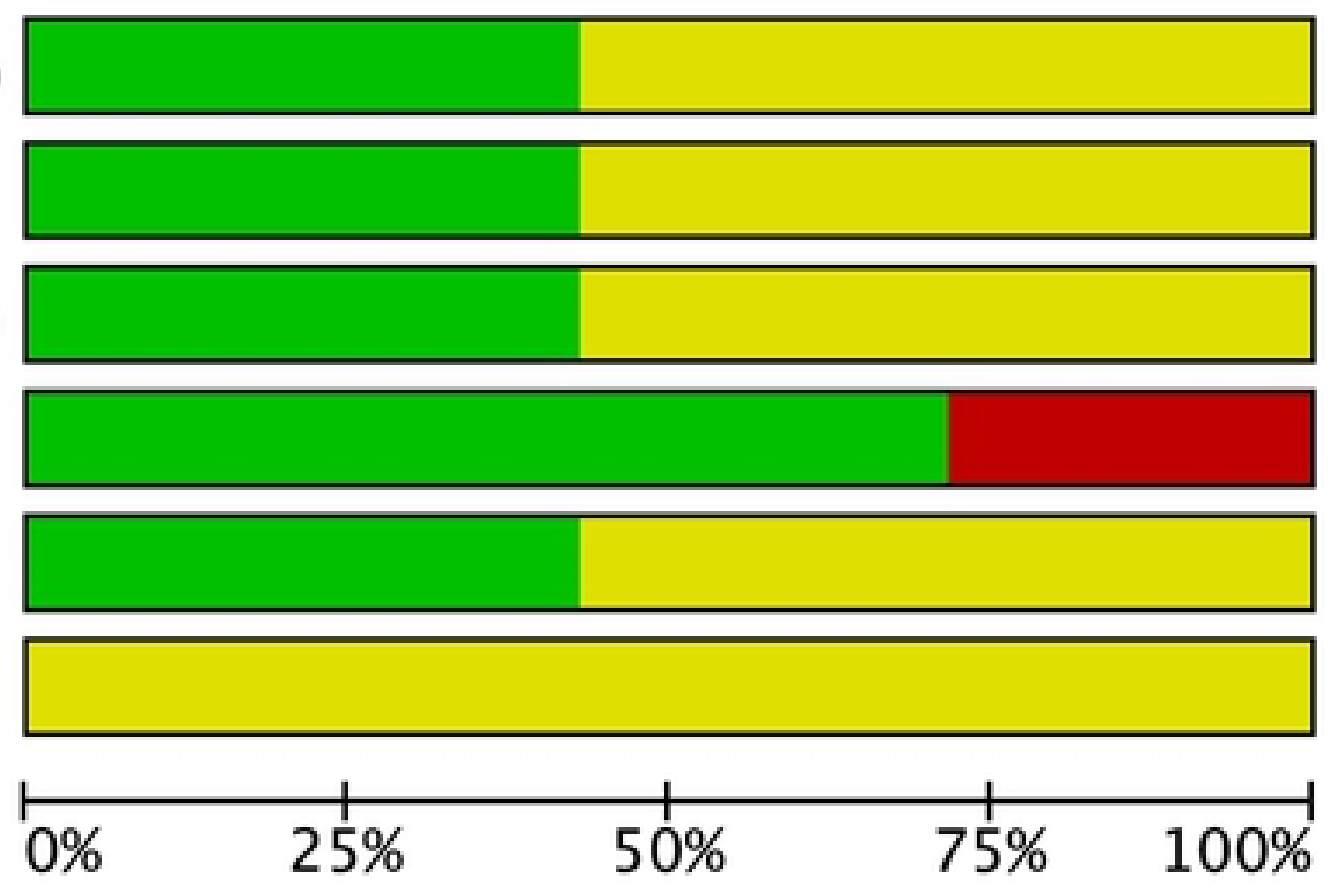

Low risk of bias

Unclear risk of bias

High risk of bias

Fig2 


\begin{tabular}{|c|c|c|c|c|c|c|c|}
\hline 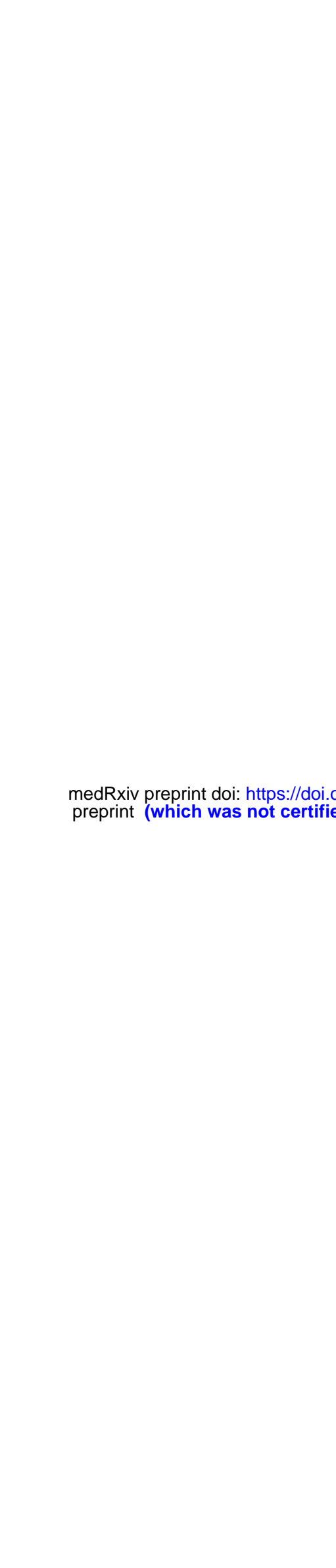 & 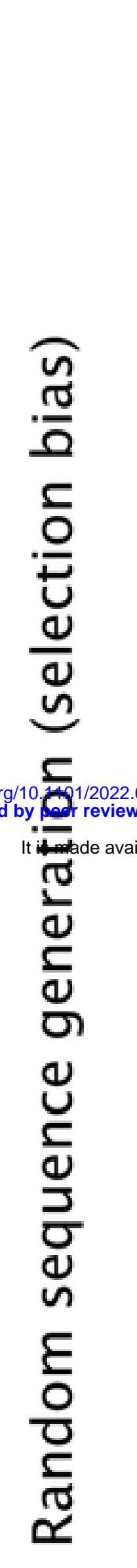 & 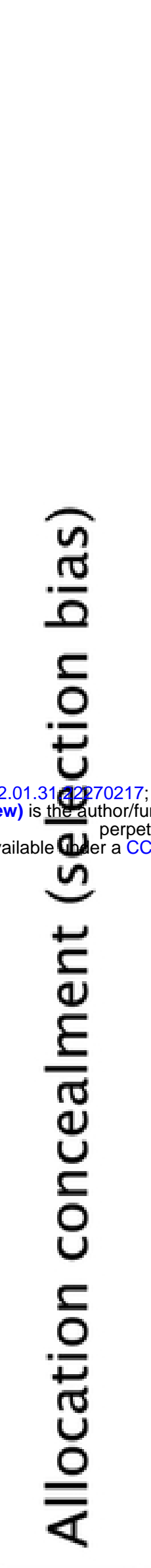 & 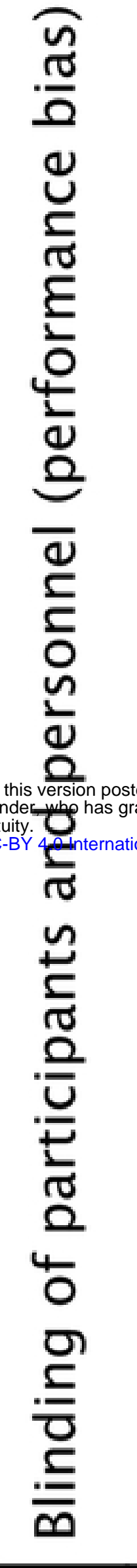 & 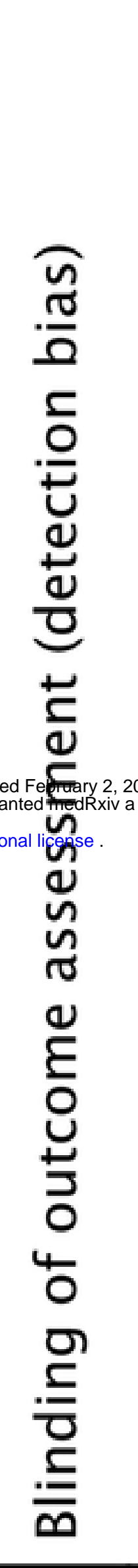 & 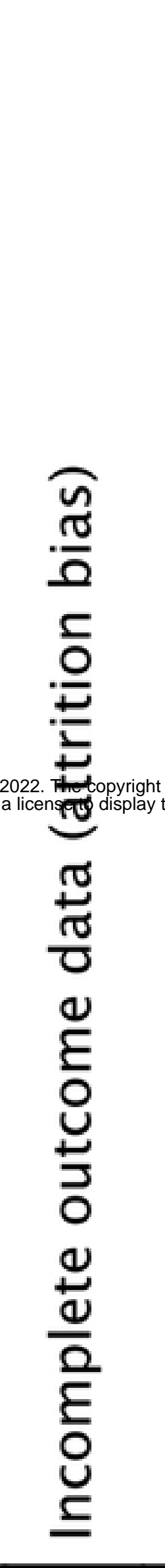 & 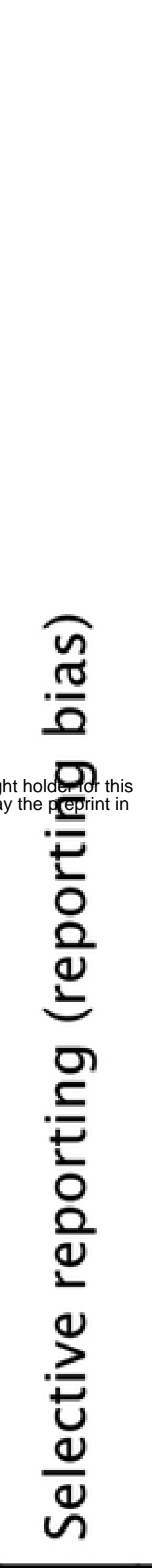 & 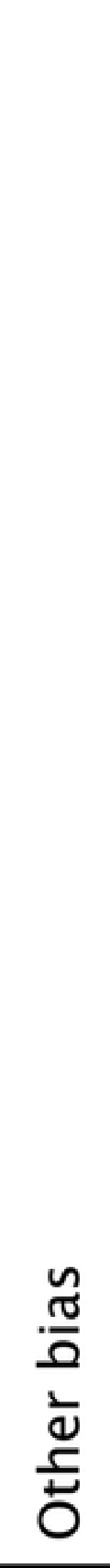 \\
\hline Dong 2021 & + & + & + & + & 0 & + & $?$ \\
\hline Gu 2019 & + & $?$ & $?$ & $?$ & + & $?$ & $?$ \\
\hline Li 2014 & + & $?$ & + & $?$ & + & $?$ & $?$ \\
\hline Mao 2021 & + & $?$ & $?$ & $?$ & + & $?$ & $?$ \\
\hline Wen 2021 & + & + & + & + & 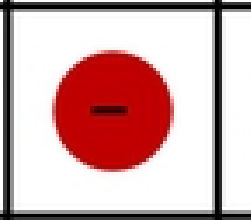 & + & $?$ \\
\hline Yu 2020 & + & $?$ & $?$ & + & + & $?$ & $?$ \\
\hline Zheng 2013 & + & + & $?$ & $?$ & + & + & $?$ \\
\hline
\end{tabular}

Fig3 


\title{
1.1.1 Electroacupuncture vs Sham acupuncture
}

$\begin{array}{lrrrrrrrr}\text { Dong } 2021 & -0.3 & 1.9 & 25 & -0.4 & 1.65 & 17 & 11.3 \% & 0.10[-0.98,1.18] \\ \text { Gu 2019 } & -1.58 & 3.36 & 38 & -0.08 & 2.8 & 38 & 8.7 \% & -1.50[-2.89,-0.11] \\ \text { Subtotal (95\% Cl) } & & & 63 & & & \mathbf{5 5} & \mathbf{2 0 . 0 \%} & -\mathbf{0 . 6 4}[-2.20,0.93]\end{array}$

Subtotal $(95 \% \mathrm{Cl})$

$17, d f=1(P=0.08) ; 1^{2}=68 \%$

Heterogeneity: $\mathrm{Tau}^{2}=0.88 ; \mathrm{Chi}^{2}=3.17, \mathrm{c}$

Test for overall effect: $Z=0.80(P=0.42)$

\subsubsection{Acupuncture plus Medicine vs Medicine}
Li 2014
$\begin{array}{ll}-2 & 1.23\end{array}$
$\begin{array}{lll}53 & -1.7 & 1.65\end{array}$
$51 \quad 16.8 \%$
$-0.30[-0.86,0.26]$
Mao 2021
$\begin{array}{ll}-2.13 & 0.52\end{array}$
$\begin{array}{lll}54 & -1.31 & 0.46\end{array}$
$54 \quad 20.0 \%$
$-0.82[-1.01,-0.63]$
Subtotal $(95 \% \mathrm{CI})$ 107
$10536.8 \%-0.63[-1.12,-0.14]$

Heterogeneity: $\mathrm{Tau}^{2}=0.09 ; \mathrm{Chi}^{2}=2.98, \mathrm{df}=1(\mathrm{P}=0.08) ; \mathrm{I}^{2}=66 \%$

Test for overall effect: $Z=2.52(P=0.01)$

\subsubsection{Acupuncture vs Metformin}

Wen 2021

Yu 2020

Zheng 2013

Subtotal $(95 \% \mathrm{CI})$

$\begin{array}{ll}-0.27 & 1.75\end{array}$

$-1.913 .12$

$\begin{array}{lll}97 & -0.89 & 1.88\end{array}$

$\begin{array}{lll}31 & -1.25 & 1.28\end{array}$

$\begin{array}{ll}-1.4 & 1.57\end{array}$

$\begin{array}{lll}43 & -1.2 & 1.59\end{array}$

$\begin{array}{rr}95 & 17.3 \% \\ 30 & 10.3 \% \\ 43 & 15.6 \% \\ 168 & 43.2 \%\end{array}$ 171

$1^{2}=66 \%$

Heterogeneity: $\mathrm{Tau}^{2}=0.27 ; \mathrm{Chi}^{2}=5.94, \mathrm{~d}$
Test for overall effect: $\mathrm{Z}=0.10(\mathrm{P}=0.92)$

\section{Total $(\mathbf{9 5 \%} \mathrm{Cl})$}

341

$328 \quad 100.0 \%$

Heterogeneity: $\mathrm{Tau}^{2}=0.37 ; \mathrm{Chi}^{2}=32.77, \mathrm{df}=6(\mathrm{P}<0.0001) ; \mathrm{I}^{2}=82 \%$

Test for overall effect: $Z=1.18(P=0.24)$

Test for subgroup differences: $\mathrm{Chi}^{2}=2.26, \mathrm{df}=2(\mathrm{P}=0.32), \mathrm{I}^{2}=11.6 \%$
Mean Difference

IV, Random, 95\% Cl

Fig4

$-0.33[-0.87,0.22]$

$0.62[0.11,1.13]$ $-0.66[-1.85,0.53]$ $-0.20[-0.87,0.47]$ $0.04[-0.70,0.78]$

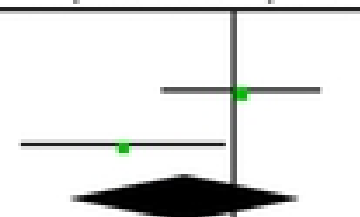

\author{
(2)
}
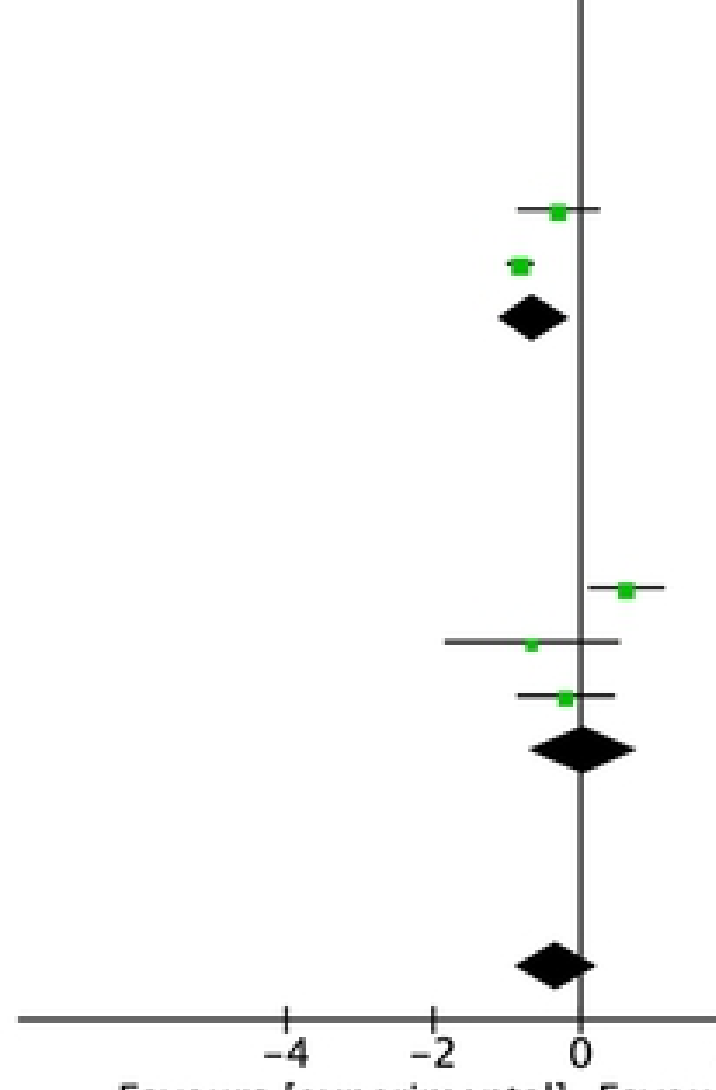

Favours [experimental] Favours [control] 


\subsubsection{Electroacupuncture vs Sham acupuncture}

$\begin{array}{lrrrrrrrr}\text { Dong 2021 } & -0.3 & 0.4 & 25 & -0.2 & 0.36 & 17 & 24.1 \% & -0.10[-0.33,0.13] \\ \text { Gu 2019 } & -0.64 & 1.47 & 38 & 0.88 & 0.54 & 38 & 19.7 \% & -1.52[-2.02,-1.02] \\ \text { Subtotal (95\% Cl) } & & & 63 & & & \mathbf{5 5} & \mathbf{4 3 . 8 \%} & \mathbf{- 0 . 7 9 [ - 2 . 1 8 , 0 . 6 0 ]}\end{array}$

Subtotal $(95 \% \mathrm{Cl})$

$\begin{array}{ccc}63 & 43.8 \% \\ 67, d f=1(P<0.00001) ; & I^{2}=96 \%\end{array}$

Heterogeneity: $\mathrm{Tau}^{2}=0.97 ; \mathrm{Chi}^{2}=25.67, \mathrm{df}=1(\mathrm{P}<0.00001) ; \mathrm{I}^{2}=96 \%$

Test for overall effect: $Z=1.12(P=0.26)$

\subsubsection{Acupuncture plus Medicine vs Medicine}
Li 2014
$\begin{array}{lllll}-0.5 & 1.41 & 53 & -0.1 & 1.82\end{array}$
$51 \quad 17.3 \% \quad-0.40[-1.03,0.23]$
Subtotal $(95 \% \mathrm{Cl})$
53
$51 \quad 17.3 \%$
$-0.40[-1.03,0.23]$

Heterogeneity: Not applicable

Test for overall effect: $Z=1.25(P=0.21)$

\subsubsection{Acupuncture vs Metformin}

$\begin{array}{lrrrrrrrr}\text { Wen 2021 } & -0.22 & 0.72 & 97 & -0.02 & 0.94 & 96 & 24.1 \% & -0.20[-0.44,0.04] \\ \text { Zheng 2013 } & -0.9 & 1.93 & 43 & -1 & 1.71 & 43 & 14.8 \% & 0.10[-0.67,0.87] \\ \text { Subtotal }(95 \% \mathrm{CI}) & & & \mathbf{1 4 0} & & & \mathbf{1 3 9} & \mathbf{3 8 . 9 \%} & -\mathbf{0 . 1 7}[-\mathbf{0 . 4 0 , 0 . 0 5}]\end{array}$

Subtotal $(95 \% \mathrm{Cl})$

140

$13938.9 \%$

Heterogeneity: $\mathrm{Tau}^{2}=0.00 ; \mathrm{Chi}^{2}=0.53, \mathrm{df}=1(\mathrm{P}=0.47) ; \mathrm{I}^{2}=0 \%$

Test for overall effect: $Z=1.51(P=0.13)$

\section{Total $(95 \% \mathrm{Cl})$}

256

$245 \quad 100.0 \%$

Heterogeneity: $\mathrm{Tau}^{2}=0.21 ; \mathrm{Chi}^{2}=27.65, \mathrm{df}=4(\mathrm{P}<0.0001) ; \mathrm{I}^{2}=86 \%$

Test for overall effect: $Z=1.83(P=0.07)$

Test for subgroup differences: $\mathrm{Chi}^{2}=1.12, \mathrm{df}=2(\mathrm{P}=0.57), \mathrm{I}^{2}=0 \%$
$0.10[-0.67,0.87]$
$-0.17[-0.40,0.05]$

$-0.43[-0.88,0.03]$

Mean Difference

IV, Random, 95\% CI

\section{Fig5}



4.1.1 Electroacupuncture vs Sham acupuncture

\section{Dong 2021}

Gu 2019

$$
-0.57 .55
$$

$-4.219 .34$ $\begin{array}{ll}25 & -1.1\end{array}$

38

63

\section{5}

611.58

Heterogeneity: $\mathrm{Tau}^{2}=3.64 ; \mathrm{Chi}^{2}=1.70, \mathrm{~d}$
Test for overall effect: $Z=0.65(P=0.52)$

\subsubsection{Acupuncture plus Medicine vs Medicine}
Li 2014
$-10.3 \quad 2.25$
$\begin{array}{lll}53 & -8.8 & 1.55\end{array}$
$51 \quad 48.8 \%-1.50[-2.24,-0.76]$
Subtotal $(95 \% \mathrm{CI})$

53
$5148.8 \%-1.50[-2.24,-0.76]$

Heterogeneity: Not applicable

Test for overall effect: $Z=3.97(P<0.0001)$

\subsubsection{Acupuncture vs Metformin}

$\begin{array}{lrrrrrrrr}\text { Wen 2021 } & -0.59 & 6.75 & 97 & -1.63 & 20.81 & 96 & 10.1 \% & 1.04[-3.33,5.41] \\ \text { Zheng 2013 } & -3.8 & 5.16 & 43 & -4.9 & 6.94 & 43 & 21.5 \% & 1.10[-1.48,3.68] \\ \text { Subtotal (95\% Cl) } & & & \mathbf{1 4 0} & & & \mathbf{1 3 9} & \mathbf{3 1 . 6 \%} & \mathbf{1 . 0 8}[-\mathbf{1 . 1 4}, \mathbf{3 . 3 1}\end{array}$

Heterogeneity: $\mathrm{Tau}^{2}=0.00 ; \mathrm{Chi}^{2}=0.00, \mathrm{df}=1(\mathrm{P}=0.98) ; \mathrm{I}^{2}=0 \%$

Test for overall effect: $Z=0.96(P=0.34)$

\section{Total $(95 \% \mathrm{CI})$}

Heterogeneity: $\mathrm{Tau}^{2}=1.12 ; \mathrm{Chi}^{2}=6.36, \mathrm{df}=4(\mathrm{P}=0.17) ; \mathrm{I}^{2}=37 \%$

Test for overall effect: $Z=0.82(P=0.41)$

Test for subgroup differences: $\mathrm{Chi}^{2}=4.67, \mathrm{df}=2(\mathrm{P}=0.10), \mathrm{I}^{2}=57.2 \%$

$-0.65[-2.18,0.89]$

Fig7 


\subsubsection{Electroacupuncture vs Sham acupuncture}

$\begin{array}{lrlllllll}\text { Dong 2021 } & -0.6 & 5.45 & 26 & -0.2 & 3.5 & 20 & 10.6 \% & -0.40[-3.00,2.20] \\ \text { Gu 2019 } & -2.02 & 4.43 & 38 & 0.71 & 2.85 & 38 & 15.1 \% & -2.73[-4.40,-1.06] \\ \text { Subtotal (95\% Cl) } & & & \mathbf{6 4} & & & \mathbf{5 8} & \mathbf{2 5 . 7 \%} & \mathbf{- 1 . 7 8 [ - 4 . 0 3 , 0 . 4 6 ]}\end{array}$

\section{Subtotal $(95 \% \mathrm{Cl}$}

Heterogeneity: $\mathrm{Tau}^{2}=1.47 ; \mathrm{Chi}^{2}=2.18, \mathrm{df}=1(\mathrm{P}=0.14) ; \mathrm{I}^{2}=54 \%$

Test for overall effect: $Z=1.56(P=0.12)$

\subsubsection{Acupuncture plus Medicine vs Medicine}
Li 2014
$\begin{array}{ll}-6 & 2.7\end{array}$
$53-5$
$-2.8 \quad 2.33$
$\begin{array}{llll}54 & -1.08 & 2.47\end{array}$
$51 \quad 19.0 \%-1.00[-1.91,-0.09]$
Mao 2021
107
$54 \quad 19.1 \%-1.72[-2.63,-0.81]$
Subtotal $(95 \% \mathrm{CI})$
$10538.1 \%-1.36[-2.07,-0.66]$

Heterogeneity: $\mathrm{Tau}^{2}=0.04 ; \mathrm{Chi}^{2}=1.21, \mathrm{df}=1(\mathrm{P}=0.27) ; \mathrm{I}^{2}=17 \%$

Test for overall effect: $Z=3.78(P=0.0002)$

\subsubsection{Acupuncture vs Metformin}

$\begin{array}{lrrrrrrrr}\text { Wen 2021 } & -0.68 & 1.15 & 96 & -1.12 & 1.38 & 96 & 21.0 \% & 0.44[0.08,0.80] \\ \text { Zheng 2013 } & -7.1 & 3.7 & 43 & -4.9 & 4.06 & 43 & 15.2 \% & -2.20[-3.84,-0.56] \\ \text { Subtotal (95\% Cl) } & & & 139 & & & 139 & \mathbf{3 6 . 2 \%} & -\mathbf{0 . 7 5}[-\mathbf{3 . 3 3}, \mathbf{1 . 8 2}]\end{array}$

Subtotal $(95 \% \mathrm{Cl})$

); $1^{2}=89 \%$

Heterogeneity: $\mathrm{Tau}^{2}=3.12 ; \mathrm{Chi}^{2}=9.48$,

Total $(95 \% \mathrm{Cl})$

310

$302100.0 \%-1.21[-2.41,-0.02]$

Heterogeneity: $\mathrm{Tau}^{2}=1.73 ; \mathrm{Chi}^{2}=40.38, \mathrm{df}=5(\mathrm{P}<0.00001) ; \mathrm{I}^{2}=88 \%$

Test for overall effect: $Z=1.99(P=0.05)$

Test for subgroup differences: $\mathrm{Chi}^{2}=0.35, \mathrm{df}=2(\mathrm{P}=0.84), \mathrm{I}^{2}=0 \%$

Fig8

Favours [experimental] Favours [control] 